\title{
Ultraviolet radiation and consumer effects on a field-grown intertidal macroalgal assemblage in Antarctica
}

\author{
KATHARINA ZACHER*, ANGELA WULFF†, MARKUS MOLIS , DIETER HANELT $\S$ and \\ CHRISTIAN WIENCKE* \\ *Alfred Wegener Institute for Polar and Marine Research, Am Handelshafen 12, D-27570 Bremerhaven, Germany, †Department of \\ Marine Ecology, Göteborg University, PO Box 461, SE-405 30 Göteborg, Sweden, †Biological Station Helgoland, Alfred Wegener \\ Institute for Polar and Marine Research, Marine Station, Kurpromenade 201, D-27498 Helgoland, Germany, §Biocentrum Klein \\ Flottbek, University of Hamburg, Ohnhorststr. 18, D-22609 Hamburg, Germany
}

\begin{abstract}
Ultraviolet radiation (UVR) research on marine macroalgae has hithero focussed on physiological effects at the organism level, while little is known on the impact of UV radiation on macroalgal assemblages and even less on interactive effects with other community drivers, e.g. consumers. Field experiments on macrobenthos are scarce, particularly in the Antarctic region. Therefore, the effects of UVR and consumers (mainly limpets were excluded) on early successional stages of a hard bottom macroalgal community on King George Island, Antarctica, were studied. In a two-factorial design experimental units [(1) ambient radiation, $280-700 \mathrm{~nm}$; (2) ambient minus UVB, 320$700 \mathrm{~nm}$ and (3) ambient minus UVR, $400-700 \mathrm{~nm}$ vs. consumer-no consumer] were installed between November 2004 and March 2005 ( $n=4$ plus controls). Dry mass, species richness, diversity and composition of macroalgal assemblages developing on ceramic tiles were followed. Consumers significantly suppressed green algal recruits and total algal biomass but increased macroalgal richness and diversity. Both UVA and UVB radiation negatively affected macroalgal succession. UVR decreased the density of Monostroma hariotii germlings in the first $\mathbf{1 0}$ weeks of the experiment, whereas the density of red algal recruits was significantly depressed by UVR at the end of the study. After 106 days macroalgal diversity was significantly higher in UV depleted than in UVexposed assemblages. Furthermore, species richness was significantly lower in the UV treatments and species composition differed significantly between the UV-depleted and the UV-exposed treatment. Marine macroalgae are very important primary producers in coastal ecosystems, serving as food for herbivores and as habitat for many organisms. Both, UVR and consumers significantly shape macroalgal succession in the Antarctic intertidal. Consumers, particularly limpets can mediate negative effects of ambient UVR on richness and diversity till a certain level. UVB radiation in general and an increase of this short wavelength due to stratospheric ozone depletion in particular may have the potential to affect the zonation, composition and diversity of Antarctic intertidal seaweeds altering trophic interactions in this system.

Keywords: Antarctica, diversity, grazing, hard bottom community, King George Island, macroalgal recruitment, ozone depletion, UV radiation
\end{abstract}

Received 18 October 2006; revised version received 11 November 2006 and accepted 7 December 2006

\section{Introduction}

The ozone layer protects all living organisms from excessive ultraviolet $B$ radiation (UVB, 280-320 nm).

Correspondence: Katharina Zacher, fax +49471 48311425,

e-mail: katharina.zacher@awi.de

(C) 2007 The Authors

Journal compilation (C) 2007 Blackwell Publishing Ltd
Owing to anthropogenic emission of ozone-depleting substances a decline in stratospheric ozone concentrations was detected in the early 1980s (Farman et al., 1985). During Antarctic spring, the ozone concentration can decrease by $>50 \%$, consequently increasing the UVB radiation reaching the Earth's surface (WMO, 
2003). Little improvement is expected for total column ozone in that region for the next several decades (Weatherhead \& Andersen, 2006). Although the release of ozone-depleting substances is declining, whether or not ozone levels will ever recover to pre-1980s values is unknown (Weatherhead \& Andersen, 2006).

The timing of the ozone depletion over Antarctica is crucial for aquatic organisms, as it coincides with the break up of sea ice, (i.e. the phase of highest water transparency; Karentz, 2003), and the season with strongest growth and reproduction for most macroalgal species Wiencke et al., (2007). Macroalgae are the major primary producers on intertidal rocky shores, providing food and shelter for a variety of associated species (Iken, 1996). Changes in macroalgal productivity or diversity are known to severely affect the structure of coastal marine food webs (Santas et al., 1998). Compared with algae from subtidal habitats, specimens from the intertidal are exposed to higher UVB regimes. Consequently, changes in species composition and species interactions due to UVR should firstly be recognized within eulittoral communities (Wahl et al., 2004).

Most UVR studies on marine macroalgae have been conducted in the laboratory, using artificial irradiance and focusing on physiological effects at the organism level. These studies indicate adverse UVB effects on macroalgal DNA (van de Poll et al., 2001; Roleda et al., 2004, 2005), growth (reviewed in Franklin \& Forster, 1997), photosynthesis (Dring et al., 1996; Hanelt et al., 1997) and an influence on the vertical zonation of macroalgae (e.g. Wiencke et al., 2004; Bischof et al., 2006 for a review). Early developmental stages of macroalgae are regarded as most susceptible to UV stress (reviewed in Coelho et al., 2000), and, therefore, harmful UV effects should be most severe during early succession.

However, in laboratory studies with single species it is not possible to detect synergistic or indirect UV effects on the community level. Furthermore, in laboratory studies unnatural ratios of UVB, UVA and photosynthetically active radiation (PAR, 400-700 nm) have been applied with a possible overestimation of UVB effects. Predictions of ecosystem response to UVR cannot be made by single trophic-level assessments. Different UV sensitivities of (e.g. algae and consumers) may lead to strong interactive effects as shown by Bothwell et al., (1994). In the marine environment, only few studies on interactive effects exist, demonstrating the significance of climatic (e.g. temperature, UVR) and ecological factors (e.g. grazing) as important drivers on macroalgal recruitment (Lotze et al., 1999; Lotze \& Worm, 2002). Recently, the effects of UVR on the succession of field grown marine macrobenthic communities were investigated in temperate and tropical regions. In these experiments, UVR was identified as a significant, but nonpersistent driver of community structure during early successional stages in macrobenthic assemblages (Lotze et al., 2002; Molis \& Wahl, 2004 but see Dobretsov et al., 2005).

Studying UV effects on Antarctic macroalgal assemblages is particularly important due to the severe ozone depletion over this region (WMO, 2003). However, to our knowledge only few field studies investigated effects of UVR on Antarctic algal assemblages (Wahl et al., 2004, Fairhead et al., 2006). To date, studies testing for interactions between UV effects and other ecologically important factors are missing.

In the light of this, we designed a two-factorial fieldexperiment to test the separate and combined effects of UVR and consumers on the early succession of an Antarctic intertidal macroalgal assemblage. The main questions were (1) whether UVR and consumer treatments influence biomass, the structure, and diversity of the macroalgal assemblage, (2) whether there is a difference between UVA and UVB radiation effects and (3) whether interactive effects of UV radiation and consumers affect macroalgal community structure.

\section{Materials and methods}

\section{Study site}

The field experiment was conducted at a rocky intertidal platform at Peñón Uno, Maxwell Bay, King George Island, Antarctica $\left(62^{\circ} 14^{\prime} \mathrm{S}, 58^{\circ} 41^{\prime} \mathrm{W}\right)$. The substratum consists of andensitic bedrock (G. Kleinschmidt, personal communication) and boulder fields. Intertidal Antarctic seaweed communities consist mainly of annual or pseudoperennial species and richness is low in comparison with temperate or tropical ecosystems (Wiencke \& Clayton, 2002). Epibenthic communities are characterized by Rhodophyta [e.g. Iridaea cordata Turner (Bory)], Heterokontophyta [e.g. Adenocystis utricularis (Bory) Skottsberg] and Chlorophyta (e.g. Monostroma hariotii Gain, Iken, 1996), as well as mobile consumers, mostly gastropods and amphipods (Ferraz Nonato et al., 2000). In the present study, the gastropod Nacella concinna Strebel among other, smaller gastropods like Laevilacunaria antarctica Martens and L. umbilicata Pfeffer was found very frequently and was according to its biomass the most important grazer on macrolagae in the intertidal. Dominant amphipod species in the area are Gondogeneia antarctica Chevreux and Djerboa furcipes Chevreux (Jazdzewski et al., 2001; B. Obermüller, personal communication). During the sampling period, the maximal tidal range was about $2 \mathrm{~m}$ at a sea surface temperature between $-1.8^{\circ} \mathrm{C}$ (spring) and $2{ }^{\circ} \mathrm{C}$ (summer). Water transparency was strongly variable, depending on glacial freshwater input and wind 
direction. UV transparency of the water body was highest in spring (e.g. November 28, 2003) with a maximal $1 \%$ depth at $16 \mathrm{~m}$ for UVB radiation, $19 \mathrm{~m}$ for UVA radiation and $>20 \mathrm{~m}$ for PAR $(400-700 \mathrm{~nm})$. Minimum concentrations of nitrate, phosphate and silicate were recorded in February at nonlimiting algal growth levels of 15, 2 and $47 \mu \mathrm{mol}$, respectively (Schloss et al., 2002).

\section{Experimental design and set-up}

Using a randomized block design, we tested in a twofactorial experiment the effects of consumers (two levels, fixed) and UV radiation (three levels, fixed) on the succession of a macroalgal assemblage $(n=4)$.

The experiment was run from November 28, 2004 to March 14, 2005 (106 days). A pilot-study was performed the year before from December 20, 2003 to March 9, 2004 (74 days). Thirty-two PVC cages $(50 \mathrm{~cm} \times 50 \mathrm{~cm} \times 12 \mathrm{~cm}$, including the control treatments) were fixed to the substratum at Peñón Uno at a minimal distance of $1 \mathrm{~m}$ to each other in the lower eulittoral (Fig. 1). Consequently, cages were submerged at a maximum depth of $2 \mathrm{~m}$. Cages were either open to all sides (open cage) or closed with plastic mesh ( $1 \mathrm{~mm}$ mesh size) to exclude macrograzers, mainly limpets (closed cage). To test for cage artefacts, partially open cages (half cages, equipped with PAB filters, $n=4$ ) were deployed by cutting two holes $(\sim 15 \mathrm{~cm} \times 5 \mathrm{~cm}=25 \%)$ into each sidewall. Using cut-off filters as cage tops, ambient UV radiation levels were manipulated (see below for details). Open cages without filter (= full sunlight, $n=4$ )

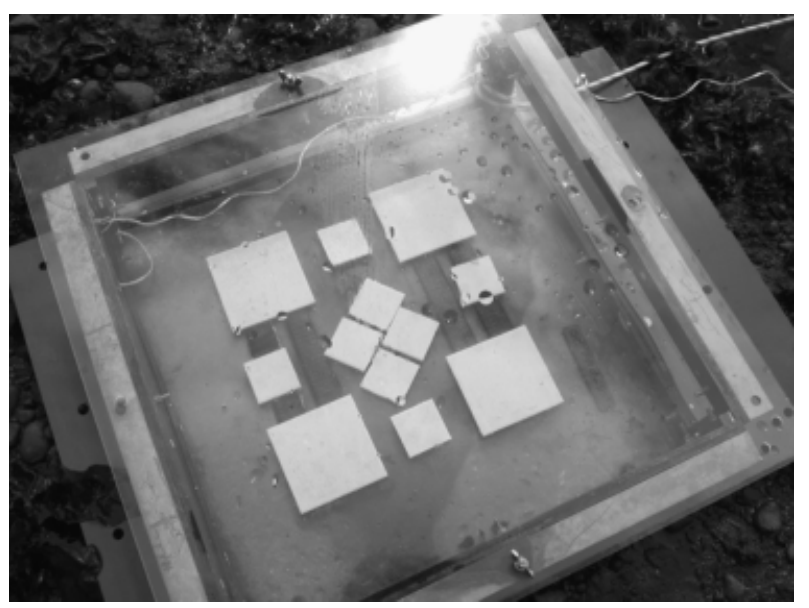

Fig. 1 Open cage allowing free access for consumers. Spatial arrangement of large and small ceramic tiles for the macro- and microalgal assemblage, respectively. Large tiles were used for macroalgae recruit identification and biomass measurements, half of the remaining small tiles for postcultivation of macroalgae and the other half for the assessment of the microalgal assemblage. were used as procedural controls to test for filter artefacts.

Unglazed ceramic tiles served as settlement substrata and were attached with Velcro to cage bottoms (Fig. 1). Each cage contained four large $(10 \mathrm{~cm} \times 10 \mathrm{~cm})$ and eight small tiles $(5 \mathrm{~cm} \times 5 \mathrm{~cm})$. At each of four sampling events, one large and one small tile were randomly withdrawn from each cage to determine treatment effects on the macroalgal and microalgal community, respectively. The results from the microalgal experiment are presented elsewhere (Zacher et al., 2007). At the end of the experiment four small tiles remained and were returned to the laboratory at Bremerhaven, Germany for cultivation.

\section{$U V$ radiation treatments}

Cut-off filters manipulated the ambient light regime in three ways. (1) $\mathrm{P}=$ PAR treatment $(>400 \mathrm{~nm})$ : using a $3 \mathrm{~mm}$ thick Perspex sheet (GS 231, Röhm, Darmstadt Germany), radiation $<400 \mathrm{~nm}$ was blocked, while filters were transparent for $91 \%$ of PAR. (2) PA = PAR + UVA treatment $(>320 \mathrm{~nm})$ : using a $3 \mathrm{~mm}$ thick Perspex sheet (GS 2458, Röhm, Darmstadt Germany) and a $0.13 \mathrm{~mm}$ transparent polyester film (Folanorm-SF/AS, folex imaging $\mathrm{GmbH}$, Cologue, Germany), radiation $<320 \mathrm{~nm}$ was blocked, while $89 \%$ of PAR and UVA passed the filter. (3) $\mathrm{PAB}=\mathrm{PAR}+\mathrm{UVA}+\mathrm{UVB}$ treatment $(>280 \mathrm{~nm})$ : using a $3 \mathrm{~mm}$ thick Perspex sheet (GS 2458, Röhm) transmitting 92\% of PAR and UV radiation. Transparency of the GS 231 and GS 2458 Perspex filters decreased on average by $1.11 \%$ ( $\mathrm{SD} \pm 0.01$ ) and $1.31 \%$ ( $\mathrm{SD} \pm 0.01$ ) per month, respectively. Therefore, only damaged filters were exchanged. Polyester films were exchanged biweekly to minimize aging and fouling effects on transparency. Filters were cleaned once or twice per week.

\section{Radiation measurements}

Weekly to biweekly, the radiation regime above the water surface, at 10 and $200 \mathrm{~cm}$ depth was recorded at a distance $\sim 50 \mathrm{~m}$ to the experimental site with a LiCor data logger (LI-1400, Li-Cor, Lincoln, NE, USA) equipped with an underwater PAR sensor (LI-192) and a Solar Light (PMA2100, Solar Light Co. Inc., Philadelphia, PA, USA) equipped with a UVB (PMA2106-UW) and a UVA radiation (PMA2110-UW) broad-band sensor. Readings were taken $\pm 1 \mathrm{~h}$ of local noon. Ambient UVA + UVB radiation was continuously recorded at the nearby $(1.5 \mathrm{~km})$ Dallmann Laboratory with a 32-channel single-photon counting spectroradiometer (Isitec, Bremerhaven, Germany). In addition, the weighted irradiance (minimal erythemal dose, $U_{\text {ery }}$ ) was measured continuously next to the cages with two 
ELUV-14 UV-dosimeters (ESYS, Berlin, Germany; El Naggar et al., 1995) to follow the underwater UV-regime and its relative changes during the experiment.

\section{Consumer abundance}

Macrobenthic consumer density in each cage was estimated in January and March 2005 (by Scuba diving). In each cage, the individuals of each gastropod species were counted and the density of amphipods estimated in categories of tens. Consumers inside closed cages were also counted and occasionally found gastropods were removed. Amphipods entering or recruiting in the closed cages could not be removed and remained inside.

\section{Sampling of macroalgae}

The density (number $\mathrm{cm}^{-2}$ ) of each macroalgal species was estimated on January 15 and 29, February 16 and March 3, 2004 (i.e. 26, 40, 58 and 74 days after starting the pilot study) and January 10, February 7 and 24 and March 14, 2005 (i.e. 43, 71, 88 and 106 days after starting the experiment). At the final sampling, four small tiles from each cage were transported in seawater filled plastic bags to Bremerhaven, Germany and cultivated under fluctuating Antarctic daylength (10$\left.30 \mu \mathrm{mol} \mathrm{m}{ }^{-2} \mathrm{~s}^{-1}\right)$ at $0{ }^{\circ} \mathrm{C}$ in a constant temperature room until most macroalgal germlings could be identified. Species identified after postcultivation served as qualitative data only and not for the statistical tests. All large tiles were sampled immediately after collection from the field at the Dallmann Laboratory. Recruit density of macroalgae was determined by counting individual germlings in five subsamples per tile $\left(\sim 50 \mathrm{~mm}^{2}\right)$ using a stereomicroscope ( $\times 16$ magnification), leaving a border of $1 \mathrm{~cm}$ unsampled to avoid edge effects. Biomass of the community was measured as dry mass, by removing and drying $\left(48 \mathrm{~h}\right.$ at $\left.80^{\circ} \mathrm{C}\right)$ all organisms from the tile. We calculated Shannon diversity $H^{\prime}$ and Margalef species richness $d$ (PRIMER ${ }^{\mathrm{TM}} 5$ software package, Plymouth Marine Laboratory).

\section{Data analysis}

A $t$-test was performed to test for differences between two independent groups (e.g. test for cage or filter artefacts). Repeated measures (RM) ANOvA was used to test for the overall effects of consumers and UV radiation over time. Because the assumption of sphericity was not met (Mauchley's test) adjusted univariate F-ratios (Greenhouse-Geyser and Huynh-Feldt) were used (Quinn \& Keough, 2002). Outcome was the same as in the RM ANOVA, therefore, we refer in the following to the former test. For separate sampling dates, a twoway ANOVA was performed to test for the effects of consumers and UV radiation on biomass, density of red and green algal recruits, species richness $d$ and diversity $H^{\prime}$ at a Bonferroni corrected significance level $(\alpha=0.0125)$ in order to lower the probability of making a type I error (Quinn \& Keough, 2002). Before analysis, data were tested for homogeneity of variances (Cochran's test). Heteroscedastic data after ln- or square-root transformation were analyzed by the nonparametric Kruskal-Wallis test. Post hoc comparisons were performed with Newman-Keuls test using STATISTI$\mathrm{CA}^{\mathrm{TM}} 6.0$ software package. Species composition of communities was compared by ANOSIM, and in case of significance, followed by SIMPER to quantify the relative contribution of species to observed dissimilarities among treatments (PRIMER ${ }^{\mathrm{TM}} 5$ software package, Plymouth Marine Laboratory). ANOSIM used a Bray-Curtis similarity matrix based on fourth root transformed density data. Results from ANOSIM were illustrated with MDS-plots.

\section{Results}

\section{Radiation measurements}

Figure 2 shows the maximal UVA and UVB irradiances measured during April 2004 and April 2005. Peak values of UVA and UVB radiation in the air were recorded in December (Fig. 2), coinciding with the highest values of underwater UVB irradiance determined as $U_{\text {ery }}$ (Fig. 3). Lowest underwater UVB values during the experiment were measured in February and March 2005 (Fig. 3). Maximum UV exposure on the tiles was reached during low tide on December 14, 2004 (around noon) were the cages were exposed to $44 \mathrm{~W} \mathrm{~m}^{-2}$ UVA and $2.3 \mathrm{~W} \mathrm{~m}^{-2} \mathrm{UVB}$, respectively. On average, $7.3 \pm 5.7 \%$ (mean $\pm \mathrm{SD}$ ) of surface UVB, $13 \pm 9.8 \%$ of UVA and $30 \pm 11.4 \%$ of PAR reached $200 \mathrm{~cm}$ water depth close to the experimental site around noon (Table 1).

\section{Consumer abundance}

The most abundant consumers during the experiment were amphipods (Table 2). Amphipod density in January was higher in half cages $(n=4)$ than in open cages ( $t$-test $=2.78, \quad P=0.032)$, indicating cage artefacts. Furthermore, their density was significantly higher (about 100\%) in closed cages in relation to open cages ( $t$-test $=-3.30, P=0.003)$. In January, $N$. concinna and other gastropod densities in open and half cages showed no significant differences $(t$-test $=2.41$, $P>0.05)$, thus no cage artefact was observed. Gastropod 


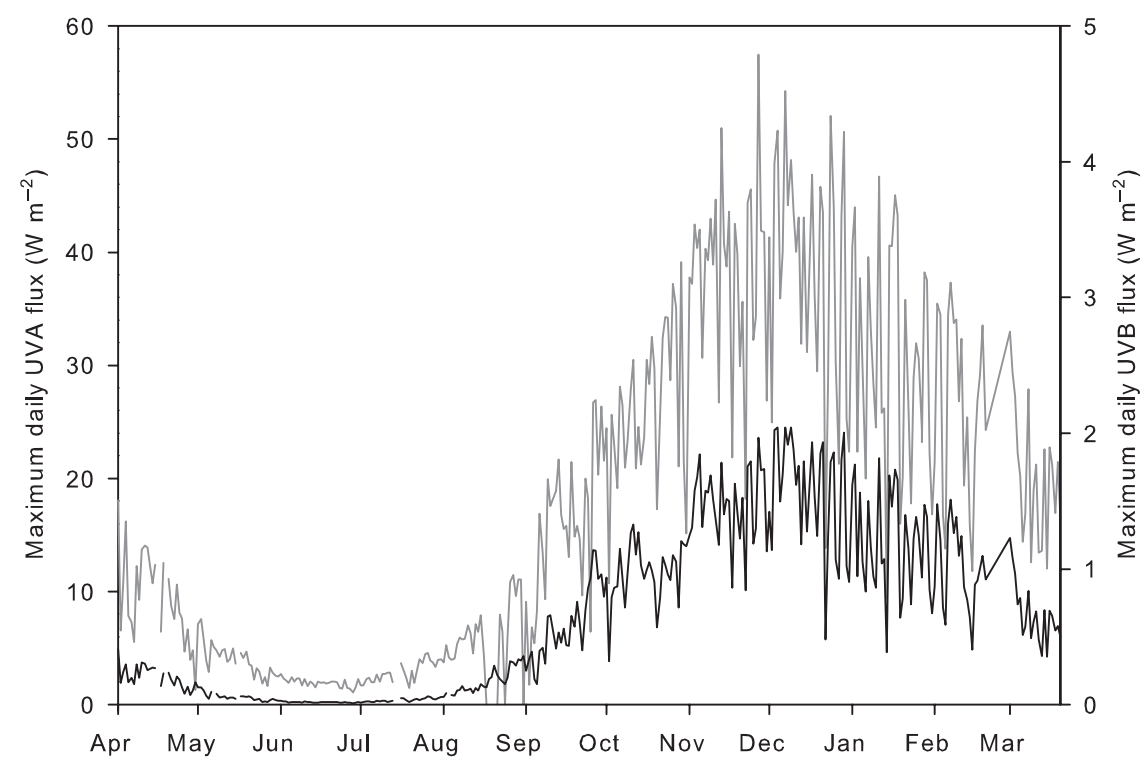

Fig. 2 Daily maximum ultraviolet A (UVA) and UVB irradiance from April 2004 to April 2005 measured at the Dallmann Laboratory (UVA gray line, UVB black line).

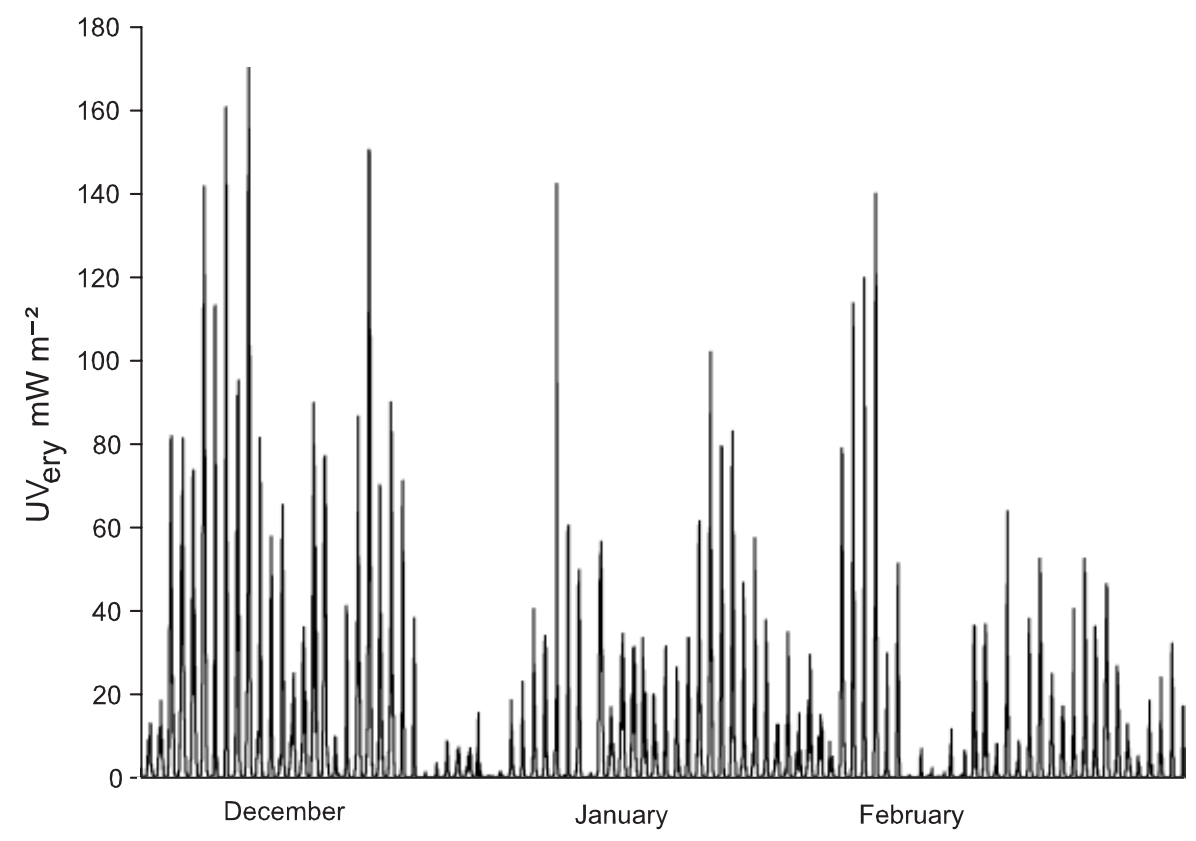

Fig. 3 Erythema weighted ultraviolet B (UVB) irradiance $\left(\mathrm{UV}_{\text {ery }}\right)$ during the duration of the experiment at Peñón Uno from December 2004 to March 2005. The sensor was located close to the cages with a maximal water column on top of $200 \mathrm{~cm}$ during high tide.

densities in closed cages were significantly lower (96\%) in comparison with open cages $(t$-test $=6.20, P<0.001)$.

In March, amphipod density was again higher in half cages than in open cages ( $t$-test $=3.66, P=0.011$, Table 2). Their density was significantly higher (about $240 \%$ ) in closed cages in relation to open cages ( $t$-test $=-4.66$, $P<0.001$ ). For gastropod densities (open and half cages) no significant differences were found $(t$-test $=1.62$,
$P>0.05)$; densities in closed cages was $40 \%$ lower compared with open cages ( $t$-test $=1.79, P>0.05)$.

No UV effects on total consumer density were detected (RM ANOVA, radiation effect, $F_{2,18}=1.69, P=0.213$ ).

\section{UVR and consumer effects}

In general, both experiments (the pilot study in 2004 and the longer experiment in 2005) gave very similar 
Table 1 Mean irradiance $( \pm S D)$ above the water surface, at 10 and $200 \mathrm{~cm}$ water depth and the percentage of the irradiance relative to surface values $(100 \%)$

\begin{tabular}{|c|c|c|c|c|c|c|}
\hline & \multicolumn{2}{|c|}{$\operatorname{PAR}\left(\mu \mathrm{mol} \mathrm{m}{ }^{-2} \mathrm{~s}^{-1}\right)$} & \multicolumn{2}{|c|}{ UVA $\left(\mathrm{W} \mathrm{m}^{-2}\right)$} & \multicolumn{2}{|c|}{ UVB $\left(\mathrm{W} \mathrm{m}^{-2}\right)$} \\
\hline & Mean & SD & Mean & SD & Mean & SD \\
\hline Above surface & 1136 & 327 & 24.1 & 12.6 & 1.4 & 0.7 \\
\hline$\%$ irradiance in $10 \mathrm{~cm}$ & 64 & 14.4 & 55 & 15.4 & 60 & 7.3 \\
\hline $10 \mathrm{~cm}$ & 734 & 291 & 13.7 & 8.4 & 0.8 & 0.4 \\
\hline$\%$ irradiance in $200 \mathrm{~cm}$ & 30 & 11.4 & 13 & 9.8 & 7 & 5.7 \\
\hline $200 \mathrm{~cm}$ & 314 & 150 & 2.9 & 2.7 & 0.1 & 0.1 \\
\hline
\end{tabular}

All measurements $\pm 1 \mathrm{~h}$ around local noon for three solar wavebands: (1) PAR (400-700 nm, $n=7)$; (2) UVA (320-400 nm, $n=12$ );

(3) UVB (280-320 nm, $n=12$ ); measured with a broad-band sensor from December 2004 until February 2005.

PAR, photosynthetically active radiation; UV, ultraviolet radiation.

Table 2 Consumer density (number of individuals) in cages from different consumer treatments

\begin{tabular}{|c|c|c|c|c|c|c|}
\hline & \multicolumn{2}{|c|}{ Closed cage $(n=12)$} & \multicolumn{2}{|c|}{ Open cage $(n=12)$} & \multicolumn{2}{|c|}{ Half cage $(n=4)$} \\
\hline & Mean & SE & Mean & SE & Mean & SE \\
\hline \multicolumn{7}{|l|}{ January } \\
\hline Nacella concinna & 0 & 0 & 3.00 & 0.82 & 2.25 & 0.95 \\
\hline Other Gastropods & 0.58 & 0.43 & 13.33 & 2.24 & 28.80 & 8.61 \\
\hline Amphipods & 28.75 & 3.15 & 14.58 & 2.92 & 22.50 & 4.79 \\
\hline \multicolumn{7}{|l|}{ March } \\
\hline Nacella concinna & 0 & 0 & 1.67 & 0.47 & 3.25 & 1.03 \\
\hline Other Gastropods & 2.58 & 0.74 & 2.67 & 0.58 & 3.50 & 1.89 \\
\hline Amphipods & 25.42 & 3.61 & 7.50 & 1.31 & 22.50 & 4.79 \\
\hline
\end{tabular}

outcomes. Table 3 gives an overview of the significant results of the two seasons. The following sections refer to the second, longer experiment.

In general, neither significant differences between open and half cages, nor between PAB and full sunlight treatments were detected for all tested parameters ( $t$-test, $P>0.05$ ), showing that there were no cage or filter artefacts.

\section{UVR and consumer effects on biomass and abundance}

Overall, both consumers and the interaction of UV radiation and consumers had a significant effect on biomass over the whole time span. These effects did not change over the duration of the experiment, shown by a nonsignificant time $\times$ treatment interaction (RM ANOVA, Table 4). For single sampling dates, no significant treatment effects on biomass were observed for either UV radiation or the interaction of UVR and consumers (Table 3). Consumers significantly reduced biomass on all sampling events (ANOVA or Kruskal-Wallis, January, $F_{1,18}=70.31, P<0.001$; early February, $H_{1,24}=16.80$, $P<0.001$; late February, $F_{1,18}=298.03, P<0.001$; March, $H_{1,24}=17.29, P<0.001$, correspondingly, Fig. 4).

The most abundant colonizer throughout the experiment was the green alga Monostroma hariotii Gain, reaching a total of $92-99 \%$ of all germlings on the tiles. Green algal recruitment was suppressed by UV radiation after 43 (ANOVA, $F_{2,18}=14.58, P<0.001$ ) and 71 days (ANOVA, $F_{2,18}=7.69, P=0.004$, Table 3, Fig. 5), but not at later samplings. During the last three sampling events, the density of green algal recruits was significantly reduced when consumers were present (day 71: ANOVA, $F_{1,18}=23.69, P=0.004$, day 88: $F_{1,18}=31.51, P<0.001$, day 106: ANOVA, $F_{1,18}=41.50, P<0.001$, Table 3, Fig. 5).

At the beginning of the experiment, very few red algal recruits settled but the density increased towards the end of the study (Fig. 5). UV radiation significantly reduced the red algal density at the end of the experiment (Kruskal-Wallis, $H_{2,24}=15.14, P=0.001$, Table 3) mostly due to UVA rather than UVB (Newman-Keuls, P:PAB and $P$ : PA, $P<0.05 ; \mathrm{PAB}: \mathrm{PA}, P>0.05)$. The density of red algal recruits was not affected by consumers.

\section{UVR and consumer effects on species composition and diversity}

Eight macroalgal species were found on the experimental tiles throughout the experiment (see Fig. 6). Three belonged to Chlorophyta ( $M$. hariotii Gain, Urospora penicilliformis (Roth) Areschoug, and Ulothrix sp.) and 
Table 3 Two-factorial ANOvA or nonparametric Kruskal-Wallis test on ultraviolet radiation (UV) and consumer (C) effects on biomass, density of Chlorophyta and Rhodophyta, species richness $d$ and diversity $H^{\prime}$ for the sampling dates (numbers one to four in the table) of both studies 2004 and 2005 (- not significant, + significant), $P$-values Bonferroni corrected (significance level $P<0.0125$ )

\begin{tabular}{|c|c|c|c|c|c|c|c|c|c|c|c|}
\hline & & \multicolumn{2}{|c|}{ Biomass } & \multicolumn{2}{|c|}{$\begin{array}{l}\text { Density } \\
\text { Chlorophyta }\end{array}$} & \multicolumn{2}{|c|}{$\begin{array}{l}\text { Density } \\
\text { Rhodophyta }\end{array}$} & \multicolumn{2}{|c|}{ Species richness } & \multicolumn{2}{|c|}{ Diversity } \\
\hline & & 2004 & 2005 & 2004 & 2005 & 2004 & 2005 & 2004 & 2005 & 2004 & 2005 \\
\hline \multirow[t]{3}{*}{1} & UV & - & - & - & + & - & - & - & - & - & - \\
\hline & $\mathrm{C}$ & + & + & - & - & - & - & - & - & - & - \\
\hline & $\mathrm{UV}: \mathrm{C}$ & - & - & - & - & - & - & - & - & - & - \\
\hline \multirow[t]{3}{*}{2} & UV & - & - & - & + & - & - & - & - & - & - \\
\hline & $\mathrm{C}$ & + & + & + & + & - & - & - & - & - & + \\
\hline & UV:C & - & - & - & - & - & - & - & - & - & - \\
\hline \multirow[t]{3}{*}{3} & UV & - & - & + & - & - & - & - & - & - & - \\
\hline & C & + & + & + & + & - & - & - & - & - & - \\
\hline & UV:C & - & - & - & - & - & - & - & - & - & - \\
\hline \multirow[t]{3}{*}{4} & UV & - & - & - & - & + & + & - & + & + & + \\
\hline & $\mathrm{C}$ & + & + & + & + & + & - & - & + & - & - \\
\hline & UV:C & - & - & - & - & - & - & - & - & - & - \\
\hline
\end{tabular}

Note that samplings one to four did not take place in the same time interval in 2004 and 2005 (see 'Materials and methods').

Table 4 RM ANOVA on UV radiation and consumer (C) effects on biomass, species richness $d$ and diversity $H^{\prime}$ (four sampling events between January and March 2005, $n=4$ )

\begin{tabular}{|c|c|c|c|c|c|c|c|}
\hline \multirow[b]{2}{*}{ Source } & \multicolumn{3}{|c|}{ Biomass } & \multicolumn{2}{|c|}{ Species richness } & \multicolumn{2}{|c|}{ Diversity } \\
\hline & $\mathrm{df}$ & $F$ & $P$ & $F$ & $P$ & $F$ & $P$ \\
\hline UV & 2 & 2.84 & 0.085 & 0.77 & 0.480 & 1.99 & 0.165 \\
\hline $\mathrm{C}$ & 1 & 33.95 & $<0.001$ & 0.17 & 0.681 & 0.56 & 0.464 \\
\hline UV:C & 2 & 39.96 & $<0.001$ & 1.52 & 0.246 & 1.27 & 0.305 \\
\hline Residuals & 18 & & & & & & \\
\hline Time & 3 & 2.36 & 0.081 & 4.35 & 0.008 & 10.87 & $<0.001$ \\
\hline Time: UV & 6 & 1.50 & 0.197 & 0.34 & 0.915 & 1.78 & 0.120 \\
\hline Time: C & 3 & 2.19 & 0.010 & 2.19 & 0.099 & 3.28 & 0.028 \\
\hline Time: UV:C & 6 & 1.66 & 0.148 & 4.53 & $<0.001$ & 6.94 & $<0.001$ \\
\hline Residuals & 54 & & & & & & \\
\hline
\end{tabular}

Bold numbers indicate significant results.

$\mathrm{UV}$, ultraviolet radiation; RM, repeated measures.

the remaining five belonged to Rhodophyta (Iridaea cordata Turner (Bory), Palmaria decipiens (Reinsch) Ricker plus three unidentified Gigartinales). During postcultivation in the laboratory, four Heterokontophyta were encountered (Petalonia fascia (Müller) Kuntze, Adenocystis utricularis (Bory) Skottsberg, Geminocarpus geminatus (Hooker et Harvey) Skottsberg, and one unidentified microthallus). Their young germlings were not detectable under the dissection microscope in Antarctica and could only be seen after being held in culture for an additional period of time. In sum, after cultivation 12 different macroalgal species were identified.
Overall, UV $\times$ consumer interactions on species richness were dependent on sampling dates (Table 4). Only at the final sampling, species richness was significantly increased by consumers (ANOVA, $F_{1,18}=11.48, P=0.003$ ) and decreased by UV (ANOVA, $F_{2,18}=6.51, P=0.007$; Table 3, Fig. 7). This was an effect of UVA rather than UVB (Newman-Keuls, P:PAB and P:PA, $P<0.05$; PAB : PA, $P>0.05$, Fig. 7).

$\mathrm{UV} \times$ consumer interactions and consumer effects on diversity significantly changed over time (Table 4). At day 71, the presence of consumers increased diversity significantly (ANOVA, $F_{1,18}=11.41, P=0.003$, Table 3, Fig. 7). At day 106, UV radiation suppressed diversity 
Table 5 Results of ANOSIM (pairwise test and Global $R, P$ ) on species composition for all sampling events, and results of SIMPER for significant results, indicating the contribution of single species to total dissimilarity in species composition due to treatment effects

\begin{tabular}{|c|c|c|}
\hline & UV PAB:P & Consumer \\
\hline After 43 days & $R=0.286, P=0.018$ & $R=0.015, P=0.300$ \\
\hline After 71 days & $R=0.323, P=0.006$ & $R=0.406, P<0.001$ \\
\hline Monostroma hariotii & $41.5 \%-$ & $35.0 \%-$ \\
\hline Palmaria decipiens & $18.8 \%-$ & $23.8 \%$ \\
\hline Red 1 & $27.1 \% \quad-$ & $24.1 \%$ \\
\hline Iridaea cordata & $12.6 \%-$ & $10.9 \%-$ \\
\hline After 88 days & $R=0.073, P=0.261$ & $R=0.291, P=0.001$ \\
\hline M. hariotii & nt & $39.0 \%-$ \\
\hline P. decipiens & nt & $19.2 \%$ \\
\hline Ulothrix sp. & nt & $19.2 \%$ \\
\hline I. cordata & nt & $14.7 \%-$ \\
\hline After 106 days & $R=0.792, P=0.001$ & $R=0.331, P=0.001$ \\
\hline M. hariotii & $17.7 \%-$ & $27.2 \%-$ \\
\hline Red 2 & $40.3 \% \quad-$ & $25.6 \%$ \\
\hline P. decipiens & $11.5 \% \quad-$ & $15.2 \%$ \\
\hline I. cordata & $15.0 \%-$ & $17.4 \%$ \\
\hline
\end{tabular}

Data were fourth root transformed, $P$-values Bonferronie corrected (significance level $P<0.0125$ ), $P A B=P A R+U V A+U V B$, $\mathrm{P}=$ PAR; nt, not tested. The direction of the effect is given as + , positive UV or consumer effect; - , negative UV or consumer effect; \pm , inconsistent.

Bold numbers indicate significant results.

PAR, photosynthetically active radiation; UV, ultraviolet radiation.

significantly (Kruskal-Wallis, $H_{2,24}=11.96, P=0.003$, Table 3). Diversity under the PAB treatment was significantly lower than under $\mathrm{P}$ treatment, with $\mathrm{PA}$ regimes resulting in intermediate levels of diversity (Newman-Keuls, $\mathrm{P}: \mathrm{PAB}, \quad P<0.05 ; \quad \mathrm{PAB}: \mathrm{PA}$ and P: PA, $P>0.05$, Fig. 7).

UV radiation affected species composition at later stages of succession (Fig. 8 for sampling 4). At day 71, species composition was significantly different between $\mathrm{PAB}$ and $\mathrm{P}$ treatments. This difference was mainly due to the strong decline in the density of recruits of the green alga $M$. hariotii and one unidentified Gigartinales recruit (Red 1) under the PAB treatments, which explained together $70 \%$ of the dissimilarity between the treatments (Table 5). Again, at day 106, species composition was significantly different between $\mathrm{PAB}$ and $P$ treatments. This difference was mostly due to the negative UV impact on the density of one unidentified Gigartinales recruit (Red 2) and M. hariotii under the PAB treatment, which explained together $60 \%$ of the dissimilarity between the treatments (Table 5). The PA treatments took an intermediate position between the $\mathrm{P}$ and the PAB treatments (Fig. 8).

Consumer affected species composition significantly during the last three samplings (e.g. Fig. 8 for sampling 4). SIMPER analysis showed that $M$. hariotii and P. decipiens recruits together explained $60 \%, 60 \%$ and $40 \%$ of the dissimilarities between the open and closed cages at the three samplings, respectively. Thereby, consumers decreased $M$. hariotii density, whereas $P$. decipiens density was favored by consumer presence (or inconsistent at sampling 3, Table 5).

\section{Discussion}

Overall, the experiments revealed significantly negative effects of ambient levels of UV radiation and consumers on the intertidal Antarctic macroalgal assemblage. The treatment effects were more pronounced at the end of the study. In general, consumer effects (mainly on biomass and recruit density) were more often observed than UV effects (affecting mainly diversity and species composition).

The pilot study showed the importance of choosing an adequate experimental period due to the slow growth of the recruits. Therefore, in the second year a maximal experimental exposure time was chosen (from sea ice break up until the end of summer). However, the general outcome of the two experiments was similar.

\section{Consumer effects}

Consumers reduced biomass of macroalgal assemblages throughout the experiment. Herbivores preferred green algae over red seaweeds, decreasing the density of green algal recruits in open and half cages 


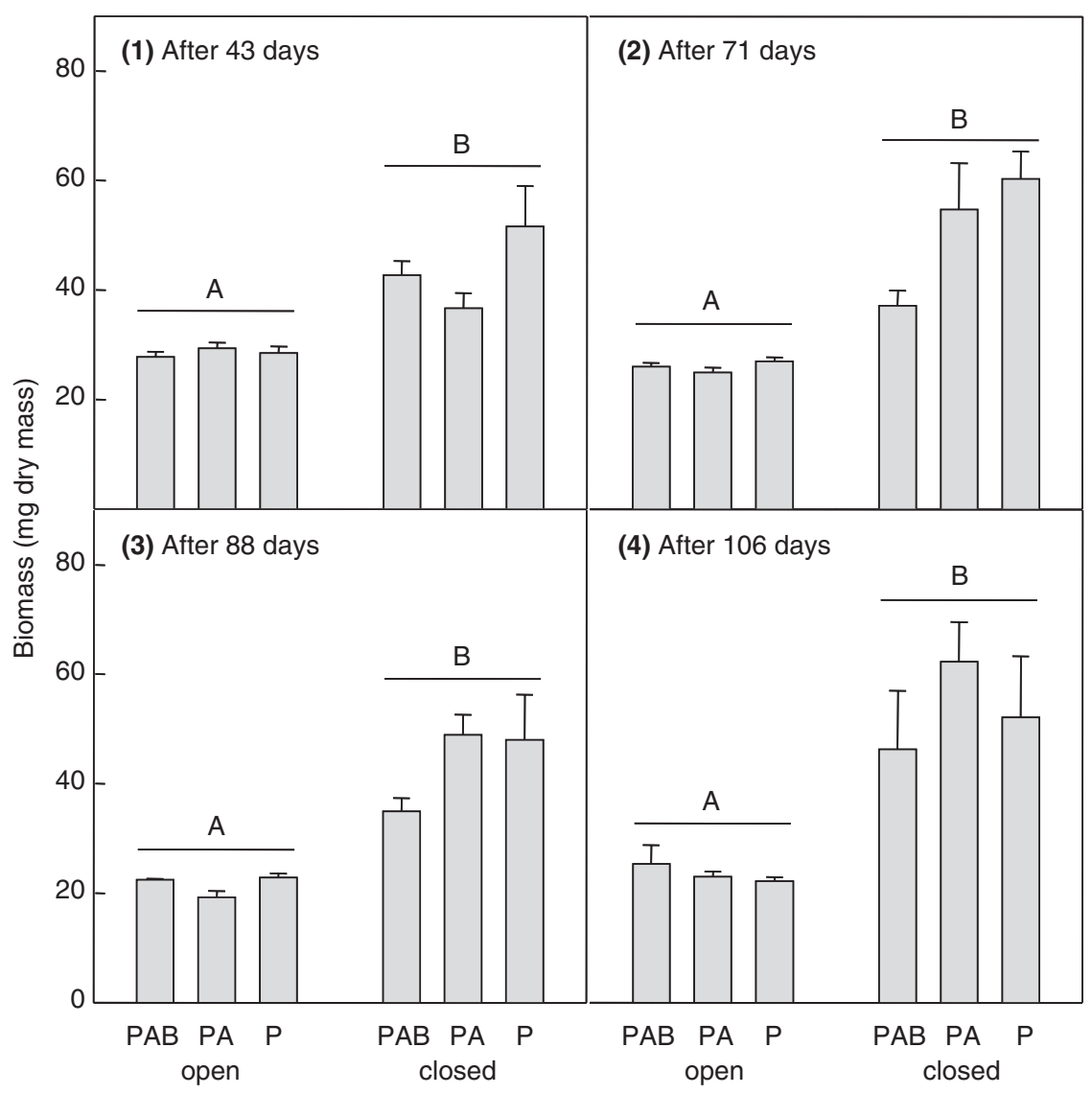

Fig. 4 Effects of ultraviolet radiation: (UV) $(\mathrm{PAB}=\mathrm{PAR}+\mathrm{UVA}+\mathrm{UVB}, \mathrm{PA}=\mathrm{PAR}+\mathrm{UVA}, \mathrm{P}=\mathrm{PAR})$ and consumers (open and closed cages) on the biomass at the four samplings (mean of total biomass of each tile $=100 \mathrm{~cm}^{2} \pm 1 \mathrm{SE}, n=4$ ). Capitals indicate significant differences between consumer treatments, i.e. A is significant different from B (as mean of the UV treatments). PAR, photosynthetically active radiation.

compared with closed cages. This effect on biomass was not caused by the small-sized amphipods, as they were not excluded by cages. Antarctic amphipods (e.g. G. antarctica) feed on some macroalgae, such as I. cordata and P. decipiens (Huang et al., 2006), but are apparently not able to graze on macroalgae during early succession were recruits are very small and well attached to the ground. Similar results were found in laboratory experiments with the green alga Enteromorpha intestinalis where snails had strong negative effects on macroalgal recruitment, whereas amphipods did not feed on Enteromorpha recruits but consumed adult Enteromorpha pieces (Lotze \& Worm, 2002). The firm attachment of recruits made it difficult to detach them, even with a brush. Thus, the impact of amphipods on early successional stages of the macroalgal species growing on our experimental tiles seems to be negligible. Other species might have been grazed by amphipods from the start and therefore do not grow in the field but later in culture (e.g. Geminocarpus). Consequently, biomass effects in our set-up were mainly caused by larger limpets, (e.g. Nacella concinna, which were successfully excluded by cages). In contrast to amphipods, N. cocinna is clearly the largest (length $\leq 46 \mathrm{~mm}$ ) and most important grazer at our study site and can reach densities from 28 to 131 ind. $\mathrm{m}^{-2}$ in the Antarctic intertidal (Brêthes et al., 1994). N. concinna mostly feeds on macroalgal propagules and benthic microalgae (Iken, 1996; Kim, 2001), whereas the smaller snail L. antarctica was shown to feed on M. hariotii, the most dominant green alga on our tiles (Iken, 1999). At the experimental site (Peñón Uno), a negative correlation between the density of $N$. concinna and macroalgae was also detected by Kim (2001), indicating effective grazing of this species. This further demonstrates the importance of gastropods, especially N. concinna as drivers on community structure in the intertidal during early macroalgal succession. For example, N. concinna and L. antarctica contributed up to $47 \%$ of the biomass of macroalgaeassociated herbivores at the study site (Iken, 1996). Grazers can also influence the diversity by e.g. increasing or decreasing the spatial heterogeneity of the system 


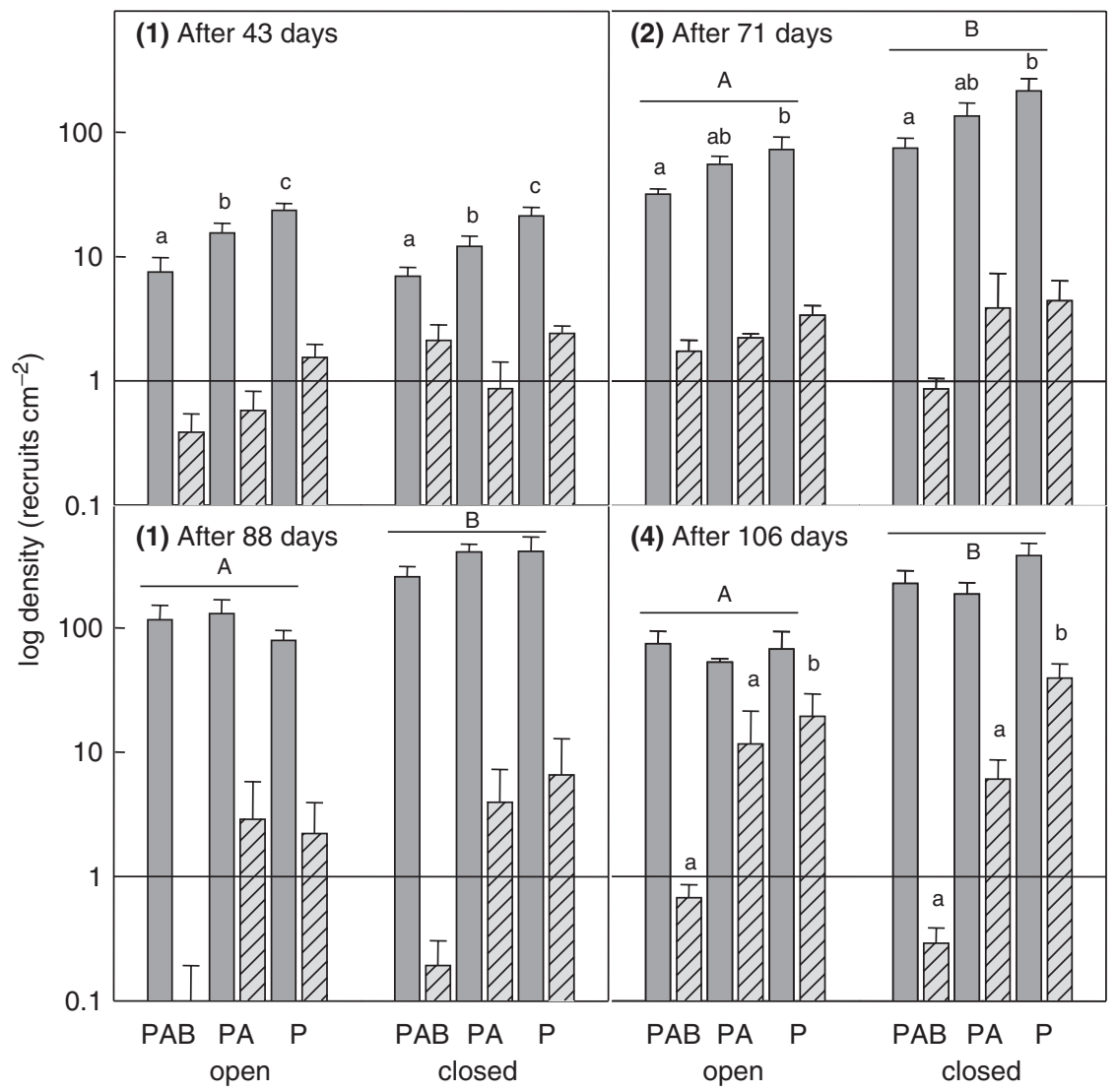

Fig. 5 Effects of ultraviolet (UV) (PAB = PAR + UVA + UVB, PA = PAR + UVA, P = PAR) and consumers (open and closed cages) on density of red (diagonal hatched) and green algal (gray) recruits at the four samplings (mean $\pm 1 \mathrm{SE}, n=4$ ). Note logarithmic scale. Lower case letters indicate significant differences between different UV treatments (as mean of closed and open treatments, respectively) and capitals significant differences between consumer treatments (as mean of the UV treatments, here only for green algal density, different letters demonstrate significant differences). If no letters were used no significant difference was found. PAR, photosynthetically active radiation.

(Sommer, 2000). Gastropods, like Littorina littorea were shown to increase the diversity by creating a diverse mosaic of microhabitats (Sommer, 2000). In our study, feeding tracks alternate with untouched biofilm (due to snail grazing) and species richness and diversity were generally higher in cages where gastropods were present.

\section{$U V$ radiation effects}

UV effects changed over time showing species-specific differences. Strongest impacts on the community structure were observed at the end of the experiment (after 3.5 months) in contrast to other studies (Santas et al., 1998; Lotze et al., 2002; Molis \& Wahl, 2004; Wahl et al., 2004 but see also Wulff et al., 1999 and Dobretsov et al., 2005). UVA radiation was mainly responsible for a decrease in recruit density and species richness whereas additional UVB had a significant negative influence on species composition and diversity. The different effects of UVB and UVA (with UVA exceeding UVB by a factor around 20 on a daily dose) demonstrated that UVB radiation was more damaging per unit irradiance, but that UVA is more damaging at the actual daily doses received (Cullen \& Neale, 1994; Wahl et al., 2004; Wiencke et al., 2006).

Green algal recruit density was decreased by UV radiation at the start of the experiment whereas red algal recruit density was most affected at the end with impacts on diversity, species richness and species composition. Several explanations for the changing nature of UV effects on the assemblage level are conceivable: (i) UV effects may match with changing radiation fluxes during the experiments, (ii) shading effects, where less UV-sensitive canopy species allow colonization of more UV-sensitive species as understorey algal and (iii) different adaptation strategies (e.g. morphology, protective substances like MAAs or phlorotannins, DNA repair mechanisms) leading to species-specific 


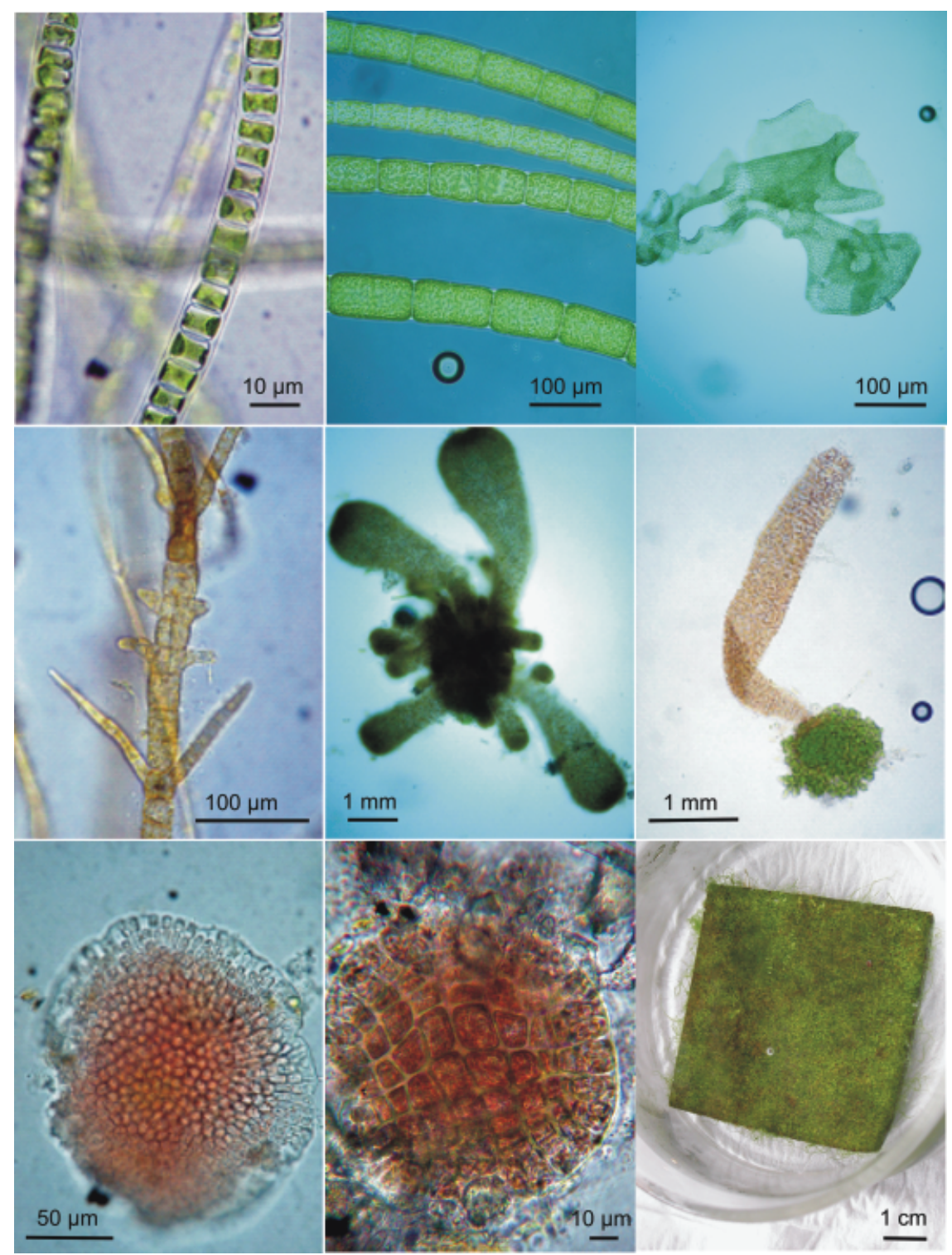

Fig. 6 Macroalgal germlings on postcultivated tiles. (first row: left Ulothrix sp., middle Urospora peniciliiformis, right Monostroma hariotii; second row: left Geminocarpus geminatus, middle Adenocystis utricularis, right Petalonia fascia; third row: left Iridaea cordata, middle Palmaria decipiens, right postcultured tile).

response to UV radiation (Lotze et al., 2002; Molis \& Wahl, 2004).

In our study, a correlation between diminishing UV effects and a decrease in UV doses over time (model i) was shown for the density of green algal recruits (i.e. its most dominant representative $M$. hariotii). An adaptation to $\mathrm{UV}$ radiation over time together with decreasing $\mathrm{UV}$ doses are possible explanations. The macrothallus of $M$. hariotii occurs in high abundance in the Antarctic intertidal. Early life stages, however, are shown to be more sensitive to UV stress compared with adults of the same species (reviewed by Coelho et al., 2000), but have the capacity to acclimate as they mature (Lotze et al., 2002).
In contrast to the green algal recruits, red algal recruits were more sensible to UV radiation during later stages of succession but early negative UV effects on red algal germlings might have been masked by low densities at the beginning of the experiment (few individuals and species settled in the first weeks and the variance between replicates was high; Dobretsov et al., 2005). Most red algae are fertile in late summer whereas green algae like $M$. hariotii release spores earlier in the season (Wiencke \& Clayton, 2002). Especially, one unidentified Gigartinales recruit (red2), occurring only at the end of the experiment was highly UV susceptible and mainly responsible for the strong UV effects on red 


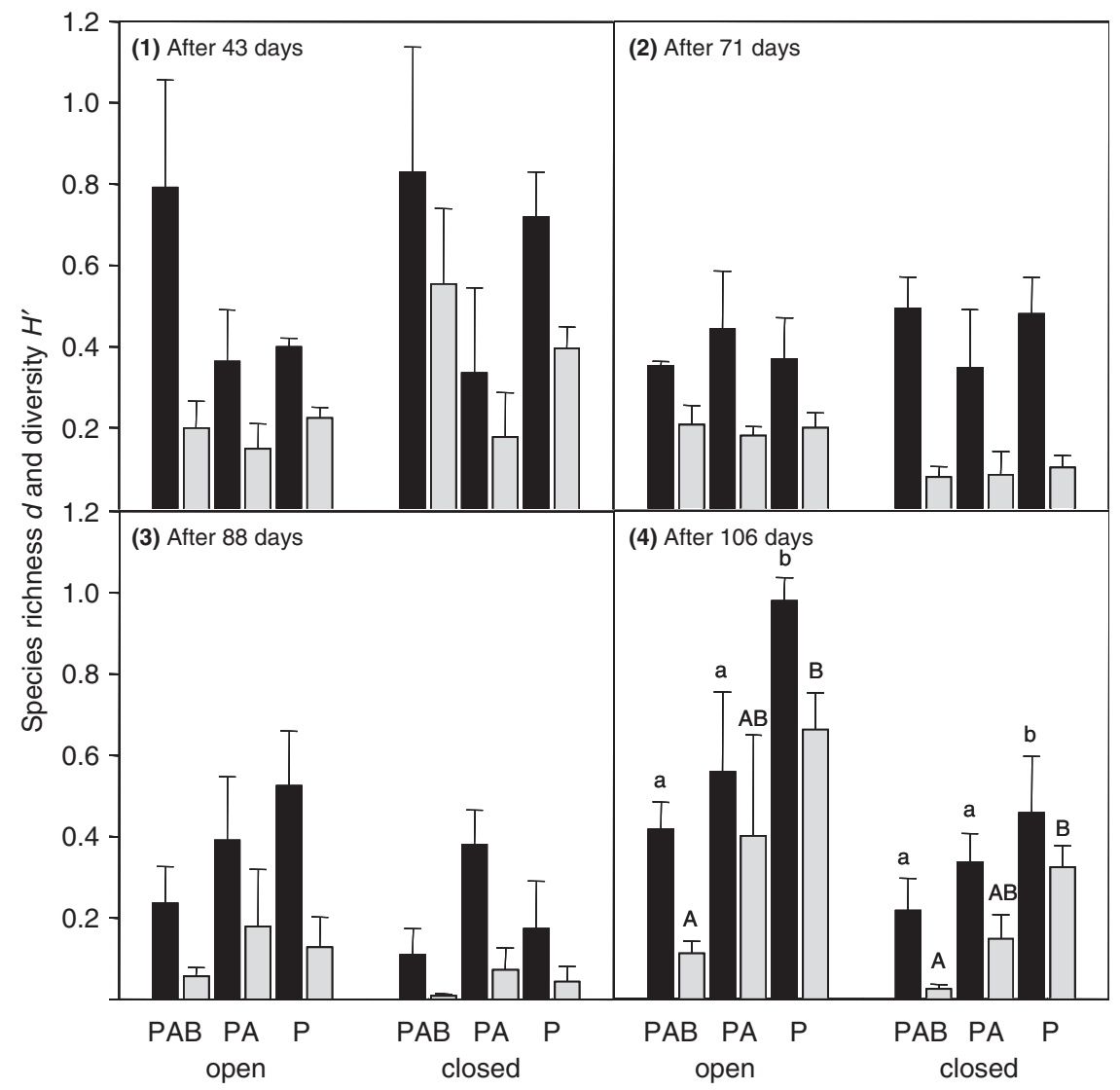

Fig. 7 Effects of ultraviolet radiation: (UV) $(\mathrm{PAB}=\mathrm{PAR}+\mathrm{UVA}+\mathrm{UVB}, \mathrm{PA}=\mathrm{PAR}+\mathrm{UVA}, \mathrm{P}=\mathrm{PAR})$ and consumers (open and closed cages) on species richness $d$ (black) and diversity $H^{\prime}$ (grey) of red and green algal recruits at the four samplings (mean $\pm 1 \mathrm{SE}, n=4$ ). Letters indicate significant differences between different $U V$ treatments, a (A) is significant different from $b(B), A B$ is not significantly different from A or B (as mean of closed and open treatments, respectively). Consumer effects on diversity were found on day 71 and for species richness for day 106 with the open cages having higher values than the closed ones. PAR, photosynthetically active radiation.

algal recruits. Macrothalli of some Antarctic red algal species (e.g. P. decipiens and I. cordata) produce MAAs which enable them to grow in the intertidal (Hoyer et al., 2001). However, little is known about MAA production in spores and germlings. In temperate and tropical regions, some UV-tolerant species provide protective shading and allow colonization of more UVsensitive species (model ii, Lotze et al., 2002; Molis \& Wahl, 2004; Wahl et al., 2004). In our experiment, however, these shading effects were lacking because propagules were still very small at the end of the experimental period. The macrothalli of many species develop in the winter period or in early spring of the following season. The UV radiation could, therefore, directly inhibit growth and influence negatively species richness and diversity.

UVB doses in Antarctica have increased for more than two decades. No long-term studies exist for this area but Karentz (2003) speculated that subtle shifts in community structure to more UV resistant species have already occurred and are continuing as a result of increased UV exposure. Species encountered in the intertidal nowadays should, therefore, be well adapted to UV radiation. However, our results show that this is only partly true for macroalgal recruits, which are species-specifically inhibited by UV radiation.

\section{Interactive UV and consumers effects}

Overall interactive effects of $\mathrm{UV} \times$ consumer were found on biomass but not for single sampling dates. Interactions between UV radiation and consumers can occur when UV induces changes in the chemical composition of algae thereby altering consumption patterns (Lotze et al., 2002). On the other hand, UV radiation can have a direct negative effect on consumers, resulting in an enhanced algal productivity (Bothwell et al., 1994). From the second to the last sampling date, the biomass was lower in the PAB treatment when consumers were 


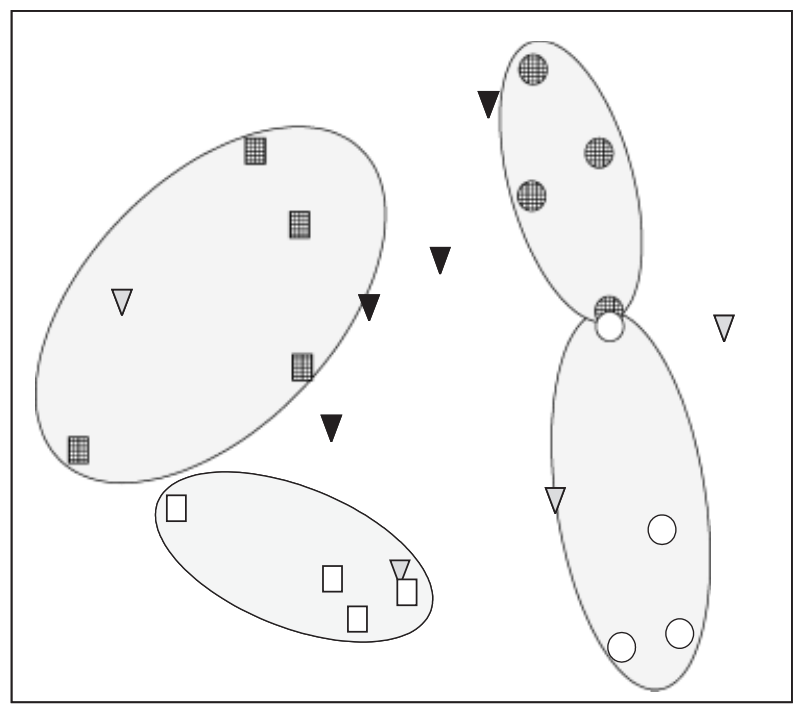

Fig. 8 MDS plot of macroalgal assemblages after 106 days (sampling 4). The species composition is different from $\mathrm{P}$ to PAB but also differs between grazed and nongrazed plots. The PA treatment does not show a clear pattern. Key: white circle, open PAB treatments; hatched circle, closed PAB treatments; gray triangle, open $\mathrm{PA}$ treatments; black triangle, closed $\mathrm{PA}$ treatments; white square, open $\mathrm{P}$ treatments; hatched square, closed $\mathrm{P}$ treatments; $n=4 ; \quad$ Stress $=0.17 . \quad \mathrm{PAB}=\mathrm{PAR}+$ UVA + UVB; PA = PAR + UVA; P = PAR; PAR, photosynthetically active radiation.

absent, but this effect was not significant for the single sampling dates. As there was no UV effect on biomass and no UV effect on consumers, we assume this to be a spurious effect.

Species composition was significantly affected by both UV and consumers due to different species and group-specific responses to radiation and consumer treatments, especially at the last sampling dates. Whereas UV radiation suppressed recruit density after 106 days, consumers favored the density of some leathery red algal recruits ( $P$. decipiens and I. cordata). Therefore, at least in some cases consumers have the potential to counteract negative UV effects. On the other hand, UV and consumer effects on $M$. hariotii and one unidentified red alga worked in the same direction further decreasing their density. In general, changes in UV radiation and consumer pressures might cause seasonal and/or spatial shifts in species composition and community structure (see also Lotze et al., 2002; Dobretsov et al., 2005).

In conclusion, our results show that Antarctic macroalgal recruits are particularly sensitive to UV radiation and consumer pressure. Consumers, especially snails, can compensate for negative effects of ambient UV on richness and diversity up to a certain level, but never reach the same level as without UV radiation. While UVB radiation had a significant negative influence on macroalgal composition and diversity a further increase, due to stratospheric ozone depletion, would influence these variables most, whereas species richness and biomass would be less affected. Therefore, we hypothesise that UVB radiation in general, and an increase of these wavelengths in particular has the potential to affect the zonation, composition and diversity of Antarctic intertidal seaweeds altering trophic interactions in this system. Whether the significant negative impact of ambient UV radiation at the end of the experiments is persistent when recruits develop into macrothalli in the next spring requires further studies. Therefore, we suggest that future research in the Antarctic region should include long-term monitoring studies considering the community development during the Antarctic winter and early spring. Combining ecological and abiotic factors would further increase our understanding of the integrated response of Antarctic species, communities and ecosystems to their changing environment (Karentz, 2003; Molis \& Wahl, 2004; Bischof et al., 2006). However, these types of experiments are, due to the extreme climatic situation in this region, difficult to perform and would require logistically difficult maintenance throughout the entire year.

\section{Acknowledgements}

This work has been done under the agreement on scientific cooperation between the AWI and DNA at Dallmann Laboratory, annex to Jubany station. The authors thank the divers J. Barenbrock, U. Barenbrock, H. Krumbeck, M. Lieneweg, M. Schwanitz and H. Zanker as well as the Argentine dive crews of the Dallmann laboratory for assistance in the field. Many thanks to G. Campana and M. L. Quartino from the Argentine Antarctic Institute. Gastropod identification by H. Zanker is acknowledged. We gratefully acknowledge financial support by the German Research Council (DFG) and the Alfred Wegener Institute for Polar and Marine Research, Germany.

\section{References}

Bischof K, Gomez I, Molis M et al. (2006) Ultraviolet radiation shapes seaweed communities. Reviews in Environmental Science and Biotechnology, 5, 141-166.

Bothwell ML, Sherbot DMJ, Pollock CM (1994) Ecosystem response to solar ultraviolet-B radiation: influence of trophiclevel interactions. Science, 265, 97-100.

Brêthes J-C, Ferreyra G, de la Vega S (1994) Distribution, growth and reproduction of the limpet Nacella (Patinigera) concinna (Strebel 1908) in relation to potential food availability, in Esperanza Bay (Antarctic Peninsula). Polar Biology, 14, 161-170.

Coelho SM, Rijstenbil JW, Brown MT (2000) Impacts of anthropogenic stresses on the early development stages of seaweeds. Journal of Aquatic Ecosystem Stress and Recovery, 7, 317-333. 
Cullen JJ, Neale PJ (1994) Ultraviolet radiation, ozone depletion, and marine photosynthesis. Photosynthesis Research, 39, 303320.

Dobretsov SV, Qian P-Y, Wahl M (2005) Effects of solar ultraviolet radiation on the formation of shallow, early successional biofouling communities in Hong Kong. Marine Ecology Progress Series, 290, 55-65.

Dring MJ, Wagner A, Boeskov J, Lüning K (1996) Sensitivity of intertidal and subtidal red algae to UVA and UVB radiation, as monitored by chlorophyll fluorescence measurements: influence of collection depth and season, and length of irradiation. European Journal of Phycology, 31, 293-302.

El Naggar S, Gustat H, Magister H, Rochlitzer R (1995) An electronic personal UV-B dosimeter. Journal of Photochemistry and Photobiology B: Biology, 31, 83-86.

Fairhead VA, Amsler CD, McClintock JB (2006) Lack of defense or phlorotannin induction by UV radiation or mesograzers in Desmarestia anceps and D. menziesii (Phaeophyceae). Journal of Phycology, 42, 1174-1183.

Farman J, Gardiner B, Shanklin J (1985) Large losses of total ozone in Antarctica reveal seasonal $\mathrm{ClO}_{x} / \mathrm{NO}_{x}$ interactions. Nature, 315, 207-210.

Ferraz Nonato E, Brito TAS, Cesar de Paiva P, Petti MAV, Corbisier TN (2000) Benthic megafauna of the nearshore zone of Martel Inlet (King George Island, South Shetland Islands, Antarctica): depth zonation and underwater observations. Polar Biology, 23, 580-588.

Franklin LA, Forster RM (1997) Review: the changing irradiance environment: consequences for marine macrophyte physiology, productivity and ecology. European Journal of Phycology, $32,207-232$.

Hanelt D, Wiencke C, Nultsch W (1997) Influence of UV radiation on the photosynthesis of Arctic macroalgae in the field. Journal of Photochemistry and Photobiology B: Biology, 38, 40-47.

Hoyer K, Karsten U, Sawall T, Wiencke C (2001) Photoprotective substances in Antarctic macroalgae and their variation with respect to depth distribution, different tissues and developmental stages. Marine Ecology Progress Series, 211, 117-129.

Huang YM, McClintock JB, Amsler CD, Peters KJ, Baker BJ (2006) Feeding rates of common Antarctic gammarid amphipods on ecologically important sympatric macroalgae. Journal of Experimental Marine Biology and Ecology, 329, 55-65.

Iken K (1996) Trophische Beziehungen zwischen Makroalgen und Herbivoren in der Potter Cove. Reports on Polar and Marine Research, 201, 1-206.

Iken K (1999) Feeding ecology of the Antarctic herbivorous gastropod Laevilacunaria antarctica Martens. Journal of Experimental Marine Biology and Ecology, 236, 133-148.

Jazdzewski K, Broyer CD, Pudlarz M, Zielinski D (2001) Seasonal fluctuations of vagile benthos in the uppermost sublittoral of a maritime Antarctic fjord. Polar Biology, 24, 910-917.

Karentz D (2003) Environmental change in Antarctica: ecological impacts and responses. In: Antarctic Biology in a Global Context (eds Huiskes AHL, Gieskes WWC, Rozema J, Schorno RML, van der Vies SM, Wolff WJ), pp. 45-55. Backhuys Publishers Leiden, the Netherlands.
Kim D (2001) Seasonality of marine algae and grazers of an Antarctic rocky intertidal, with emphasis on the role of the limpet Nacella concinna Strebel (Gastropoda: Patellidae). Reports on Polar and Marine Research, 397, 1-120.

Lotze HK, Schramm W, Schories D, Worm B (1999) Control of macroalgal blooms at early developmental stages: Pilayella littoralis versus Enteromorpha spp. Oecologia, 119, 46-54.

Lotze HK, Worm B (2002) Complex interactions of climatic and ecological controls on macroalgal recruitment. Limnology and Oceanography, 47, 1734-1741.

Lotze HK, Worm B, Molis M, Wahl M (2002) Effects of UV radiation and consumers on recruitment and succession of a marine macrobenthic community. Marine Ecology Progress Series, 243, 57-66.

Molis M, Wahl M (2004) Transient effects of solar ultraviolet radiation on the diversity and structure of a field-grown epibenthic community at Lüderitz, Namibia. Journal of Experimental Marine Biology and Ecology, 302, 51-62.

Quinn GP, Keough MJ (2002) Experimental Design and Data Analysis for Biologists. Cambridge University Press, Cambridge, UK.

Roleda MY, van de Poll WH, Hanelt D, Wiencke C (2004) PAR and UVBR effects on photosynthesis, viability, growth and DNA in different life stages of two coexisting Gigartinales: implications for recruitment and zonation patterns. Marine Ecology Progress Series, 281, 37-50.

Roleda MY, Wiencke C, Hanelt D, van de Poll WH, Gruber A (2005) Sensitivity of Laminariales zoospores from Helgoland (North Sea) to ultraviolet and photosynthetically active radiation; implications for depth distribution and seasonal reproduction. Plant, Cell and Environment, 28, 466-479.

Santas R, Korda A, Lianou Ch, Santas Ph (1998) Community response to UV radiation. I. Enhanced UVB effects on biomass and community structure of filamentous algal assemblages growing in a coral reef mesocosm. Marine Biology, 131, 153-162.

Schloss IR, Ferreyra GA, Ruiz-Pino D (2002) Phytoplankton biomass in Antarctic shelf zones: a conceptual model based on Potter Cove, King George Island. Journal of Marine Systems, 36, 129-143.

Sommer U (2000) Benthic microalgal diversity enhanced by spatial heterogeneity of grazing. Oecologia, 122, 284-287.

van de Poll WH, Eggert A, Buma AGJ, Breemann AM (2001) Effects of UV-B induced DNA damage and photoinhibition on growth of temperate marine red macrophytes: habitatrelated differences in UV-B tolerance. Journal of Phycology, 37, 30-37.

Wahl M, Molis M, Davis A et al. (2004) UV effects that come and go: a global comparison of marine benthic community level impacts. Global Change Biology, 10, 1962-1972.

Weatherhead EC, Andersen SB (2006) The search for signs of the recovery of the ozone layer. Nature, 441, 39-45.

Wiencke C, Clayton MN (2002) In: Synopsis of the Antarctic benthos: Antarctic Seaweeds, Vol. 9 (ed. Wägele JW), A.R.G. Ganter Verlag KG, Ruggell. 1, 239 pp.

Wiencke C, Clayton MN, Gómez I et al. (2007) Life strategy, ecophysiology and ecology of seaweeds in polar waters. 
Reviews in Environmental Science and Biotechnology, 6, 95126.

Wiencke C, Clayton MN, Schoenwaelder M (2004) Sensitivity and acclimation to UV radiation of zoospores from five species of Laminariales from the Arctic. Marine Biology, 145, 31-39.

Wiencke C, Roleda MY, Gruber A, Clayton MN, Bischof K (2006) Susceptibility of zoospores to UV radiation determines upper depth distribution limit of Arctic kelps: evidence through field experiments. Journal of Ecology, 94, $455-463$.
WMO (World Meteorological Organization). (2003) Scientific Assessment of Ozone Depletion: 2002. In: Global Ozone Research and Monitoring Project - Report No. 47, Geneva, 498 pp.

Wulff A, Nilsson C, Sundbäck K, Wängberg S-A, Odmark S (1999) UV radiation effects on microbenthos - a four month field experiment. Aquatic Microbial Ecology, 19, 269-278.

Zacher K, Hanelt D, Wienche C, Wulff A (2007) Grazing and UVradiation effects on an Antarctic intertidal microalgal assemblage - a long-term field study. Polar Biology, (in press). 